\title{
Efforts in Improving Overall Equipment Effectiveness (OEE) of Weaving Machine in Tire Cord Division at Tire Manufacturing Company in Indonesia
}

\author{
Akhmad Fauzi ${ }^{1}$, Gimbal Doloksaribu ${ }^{2}$ \\ Master's Program in Industrial Engineering, Mercu Buana University, Jakarta, Indonesia
}

\begin{abstract}
Weaving is one part of the production department at a manufacturing company in Indonesia that operates in the process of tire cord making, which cannot evade from problems relating to the machine effectiveness caused by the Six Big Losses. Therefore, effective and efficient measures are needed in machine maintenance to overcome and prevent the mentioned problems. The aim of this research is to investigate what the value of the effectiveness of the weaving machine is, to conduct statistical analyses to determine the most dominating factors affecting the inefficiency, and to obtain solutions for improvement based on Total Productive Maintenance (TPM). This research used the measuring method Overall Equipment Effectiveness (OEE), the analysis of the calculation of the Six Big Losses, and the Cause and Effect diagram to find existing problems and to offer suggestions to fix the problems. The results of this research show that the average $\mathrm{OEE}$ of the weaving machine was $71.7 \%$ with the availability rate of $86.3 \%$, performance efficiency of 83.6\%, and quality rate of 99.1\%. The most dominating factor influencing the low effectiveness of the Weaving was reduced speed losses; the suggested corrective action is to implement autonomous maintenance in accordance with TPM.
\end{abstract}

Keywords: Weaving, Tire cord, Total Productive Maintenance, Overall Equipment Effectiveness, Six Big Losses

\section{Introduction}

The era of globalization is marked by the open trade which means goods and services produced by any country will be traded freely and will compete in every country. The open trade era is very profitable if viewed from the customers' perpective, as they offer various alternatives in fulfilling their needs of goods and services. A customer will choose goods or services thought to be of the highest quality at relatively affordable prices. In the free trade era, high fare impositions will certainly be no longer valid. In fact, it is possible that fare hindrance will no longer exist. This will trigger a high level of competition between producers [1]. The production division in any company is often faced with several problems such as delays, idle employees, and loss of effective time for producing output, and therefore affecting the company's productivity. To reduce those problems a company should be supported by adequate tools and skilled labor to carry out the production process.

Industrial companies need continuous maintenance and treatment of their manufacturing machines. Without being under optimum conditions, the production process will not achieve its expected productivity rate. Maintenance is an activity that is done repeatedly with the goal of keeping the equipment to consistently be under the same condition with the original state [2]. Maintenance and treatment are the activities to ensure that the machines or tools function as expected. The goals of those two are to make the machines available in under acceptable conditions, to make the spare parts ready for emergency, to ensure the safety of human and nature, and to prolong the machine's period of use [3]. For those reasons, losses such as time-inefficiency, production speed, and other factors can be avoided or minimized.
TPM enables companies to carry out maintenance programs on production machines so that the production process can run effectively and efficiently. Total Productive Maintenance (TPM) is a unique Japanese philosophy that combines preventive maintenance and labor involvement. TPM is an innovative system to maintain machines, which optimizes effectiveness, eliminates defects, and promotes all operators on a daily autonomous program [4]. TPM is an innovative approach to optimize the effectiveness of equipment, reducing breakdown, and to encourage operators to implement self-maintenance (autonomous maintenance) through daily activities that involve the workers as a whole [5]. TPM aims to use machines as effectively as possible by removing waste and losses that are caused by machine malfunction, organization and adjustment, speed loss, process defects and results reduction. Besides that, TPM aims to improve productivity by increasing personnels' skills by changing the culture of the company. Furthermore, the production process that concerns quality will produce high quality products of no defects so that waste and inefficiency can be avoided. Thus, the cost of production per unit will be low and the price of the product will be competitive. TPM is a summary of eight different sections known as the pillars of TPM. Each pillar has a responsibility in different areas, but the areas overlap each other. Those eight pillars are: initial phase maintenance, health and safety, education and training, autonomous maintenance, planned maintenance, quality maintenance, focused improvement, and support systems [6].

In the tire-manufacturing industry, there are certain known fundamental elements: rubber, tire cord, carbon black, oil, and others. From those mentioned, the most important aspect is the tire cord. The tire cord is the structure of the tire, comparable to steel in concrete. The tire cord gives the shape 


\section{International Journal of Science and Research (IJSR) \\ ISSN (Online): 2319-7064}

Index Copernicus Value (2013): 6.14 | Impact Factor (2015): 6.391

of the tire; consists of pressured-air; is durable and longlasting; and can tolerate heavy loads.

In the process of tire cord making, there are 3 main steps, specifically Twisting, weaving, and Dipping. This research intends to study the weaving process from January 2014 to December 2014, which has seen a decline in the OEE score. OEE is a benchmark for some processes in TPM [7]. This is what will be discussed further in order to examine how to improve the OEE scores.

Based on this condition the main goals in this research are to analyze why OEE did not meet the target and to develop solutions to improve the implementation of the machine maintenance system by offering suggestions to fix the problems in accordance with Total Productive Maintenance (TPM).

The standards of TPM are that the availability is above $90 \%$; performance efficiency is above $95 \%$; and quality product is above $99 \%$. Therefore, the ideal OEE is above $85 \%$ as a world class performance [8].

\section{Six Big Losses}

The key objective of TPM is to eliminate or minimize all losses relating to the manufacturing system to improve OEE. In this early phase the TPM focuses on eliminating the Six Big Losses, which results in low OEE; involving equipment failure, set up and adjustment loss, idling and minor stoppage, reduced speed, defect in process, and reduced yield.

Ahuja and Khamba did some research on TPM review and directions and concluded that TMP is a global strategy to increase competitive advantage, providing directions so that a company can achieve world class organization and become the leader in competitions. Some benefits of the TPM are: improvement of OEE by $14-15 \%$, reduced stocks by $45-58 \%$, increased output of production by $22-41 \%$, reduced rejection from customers by $50-75 \%$, reduced accidents by $90-98 \%$, reduced maintenance costs by $18-45 \%$, reduced defects and reworks by $65-80 \%$, reduced breakdowns by $65-78 \%$, reduced energy costs by $8-27 \%$, and increased employees' feedback by $32-65 \%$ [9]. Kumar did some research on applications for total productive maintenance (TPM) with the purpose to provide an overview of the eight pillars of TPM implementation in a spinning machine and the OEE results after TPM was $68.4 \%$ [10]. Sivakumar also did some research at an electronic company in Malaysia. The methodology used was the 10 step TPM, OEE, Pareto chart, and MTBA. Focused improvement managed to reduce 2,066 ppm, from 2,716 ppm to $650 \mathrm{ppm}$ [11]

\section{Methodology}

\subsection{Research design}

In this research, the combination of descriptive and causal (explanatory) research was used, where descriptive design was used to describe data calculation and analysis of each research variable, while causal design was used to measure how strong the relationship and influence between the variables in the research was. This research focuses on the data and feedback collection, which were used to solve broader and vague problems into sub-problems that are narrower, more precise, and more focused.

\subsection{Data collection techniques}

The data needed to support the solution of the problem can be divided into 2 according to source, which are primary data obtained from primary sources by direct field study at a company or direct observation at the location where research is conducted, and where the employees who are directly involved in the business operations are interviewed in person. The data obtained are those of the production process, machine work system, and others. Secondary data are the documentation of the company, previous research findings, and other types of data. In this research, the secondary data needed are the output of production, production capacity, the number of defect products, and others.

\subsection{Population and sample}

Population is the area being generalized which consists of objects or subjects possessing the qualities to be studied and then concluded. In this research, the population used was all of the records of production data of the weaving section in the tire cord division at a tire companiy in Indonesia. The samples taken in this research were the records of production and downtime data from January 2014 to June 2015.

\subsection{Data analysis technique}

The data collected were then analyzed to be used in this research. The steps for data analysis taken in this research are to investigate the effectiveness levels of the use of the machine, and to derive solutions for problems. The first step is Availability Ratio Calculation. Availability shows the level of the availability or the readiness of the production machines to be used in the production process. The second step is Performance Efficiency Calculation. Performance rate is the ratio of quantity of products manufactured during the ideal cycle to the available time to complete the production process. In other words, it is the ratio between actual output and the products manufactured. The third step is Quality of Product Rate Calculation. Quality Rate is the ratio that shows the machine's capability in producing pre-determined standard products. And the last step is Overall Equipment Effectiveness Calculation. The value of effectiveness in a factory is the result of the multiplication of the three OEE variables.

\section{Data and Analysis}

\subsection{Research Data}

The data used in this research were the production data from January 2014 to June 2015, where the object of the research is the production process of the weaving machine, being one of the machines in the process of making tire cords, in which 


\section{International Journal of Science and Research (IJSR) \\ ISSN (Online): 2319-7064}

Index Copernicus Value (2013): 6.14 | Impact Factor (2015): 6.391

occurred several breakdowns that could halt the production process.

\subsection{The result of measuring machine effectiveness}

a) Availability of production equipment

Availability shows the level of availability or readiness of production equipment to be used in the production process. A machine with a high availability level indicates that the machine is always in a standby state whenever it needs to be used. The availability rate of the weaving machine was $86.3 \%$.

\section{b)Performance Rate of production process}

Performance rate is the ratio of product manufactured quantity within the ideal cycle to the time available for the production process. It is the ratio between actual output and the products manufactured. The Performance Rate of the weaving machine was $83.6 \%$.

\section{c) Quality Rate}

Quality Rate is the ratio explaining the machine's capability in producing pre-determined standard products. The Quality Rate of the weaving machine was $99.1 \%$.

\section{d)Overall Equipment Effectiveness (OEE)}

The effectiveness rate in the factory on the weaving machine is the result of multiplying the three OEE variables, which are the values of availability $x$ performance efficiency rate $\mathrm{x}$ quality rate; thus with the Availability rate at $86.3 \%$, the Performance Efficiency was $83.6 \%$.

\subsection{The Six Big Losses measurement results}

To take a more detailed look at the Six Big Losses that affected the weaving machine's effectiveness, time loss measurement was calculated for each factor in the Six Big Losses. The first factor is reduced speed losses with a total time loss of $157,653.3$ hours and a rate of $74.01 \%$. The second factor is breakdown losses with a total time loss of $25,474.8$ hours and a rate of $11.96 \%$. The third factor is idling and minor stoppages with a total time loss of $15,981.0$ hours and a rate of $7.5 \%$. The fourth factor is set up and adjustment losses with a total time loss of $13,836.5$ hours and a rate of $6.50 \%$. The fifth factor is yield/scrap losses with a total time loss of 57.7 hours and a rate of $0.03 \%$. The last factor is rework losses with a total time loss of 24.7 hours and a rate of $0.01 \%$.

From the list of percentages above which will be depicted in the Pareto diagram, it is clear in what order the six factors affect the effectiveness of the weaving machine. The diagram shows that the largest percentage is reduced speed losses. The Pareto chart for the weaving machine is depicted below:

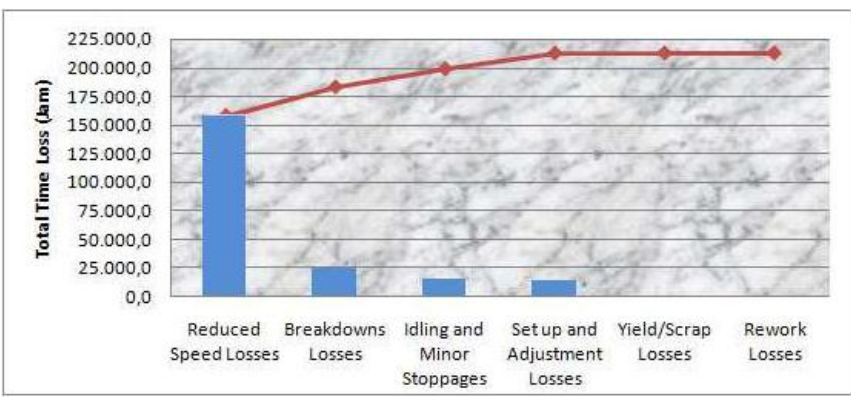

Figure 1: Pareto chart of the percentages of the Six Big Losses factors on the Weaving machine

\subsection{Testing using the Product Moment Pearson correlation between OEE score and the Six Big Losses}

Based on the data of the Six Big Losses above it can be seen that the factors having high percentages were Reduced Speed Losses, Breakdowns Losses, Idling and Minor Stoppages, and Set up and Adjustment Losses; while the two last factors, Yield/Scrap Losses and Rework Losses, had low percentages. Therefore, to take a clearer look at the Six Big Losses that affected the effectiveness of the weaving machine, a Product Moment Pearson correlation test between the OEE score and the Six Big Losses was conducted. In this Product Moment Pearson analysis correlation test, two linear relationships between two independent variables (X1, $\mathrm{X} 2, \ldots . \mathrm{Xn})$ and a dependent variable $(\mathrm{Y})$ were scrutinized This analysis is to investigate the relationship between the independent and dependent variables, whether they have a correlation or not. The formula of this test is as follows:

$$
\text { n } \sum X Y-\sum X . \sum Y
$$

$$
\mathrm{r}=\quad \sqrt{ }\left[\mathrm{n} \sum \mathrm{X}^{2}-\left(\sum \mathrm{X}\right)^{2}\right]\left[\mathrm{n} \sum \mathrm{Y}^{2}-\left(\sum \mathrm{Y}\right)^{2}\right]
$$

Table 1: Interpretation of $r$ value in Product Moment Pearson correlation

\begin{tabular}{|c|c|}
\hline $\mathrm{r}$ & Interpretation \\
\hline 0 & Not correlated \\
\hline $0.01-0.20$ & Very low correlation \\
\hline $0.21-0.40$ & Low \\
\hline $0.41-0.60$ & Quite low \\
\hline $0.61-0.80$ & Enough \\
\hline $0.81-0.99$ & High \\
\hline 1 & Very high \\
\hline
\end{tabular}

The independent variables measurements used are:

- Reduced Speed Losses

- Breakdown Losses

- Idling and Minor Stoppages

- Set up and Adjustment Losses

- Yield/Scrap Losses

- Rework Losses

The dependent variable is: $\mathrm{OEE}$

The relationship of the Pearson equation between $O E E$ (Y) and the $X$ variables 


\section{International Journal of Science and Research (IJSR) \\ ISSN (Online): 2319-7064}

Index Copernicus Value (2013): 6.14 | Impact Factor (2015): 6.391

This analysis aims to investigate the relationship between the independent variables $(\mathrm{X})$ and the OEE variable (Y), whether they are correlated or not.

The OEE score is represented with a "Y". The calculation was conducted manually. The output of the Pearson analysis between the OEE score (Y) and the independent variables (X) was:

Table 2: The result of coefficient correlation (r) between OEE (Y) and X variable

\begin{tabular}{|c|c|c|}
\hline Relationship & $\mathrm{r}$ & Interpretation \\
\hline Y VS X1 & 0.575 & Quite low \\
\hline Y VS X2 & 0.659 & Enough \\
\hline Y VS X3 & 0.543 & Quite low \\
\hline Y VS X4 & 0.716 & Enough \\
\hline
\end{tabular}

Based on the interpretation, out of the six variables: $\mathrm{X} 1, \mathrm{X} 2$, $\mathrm{X} 3, \mathrm{X} 4, \mathrm{X} 5$, and $\mathrm{X} 6$, the ones that had impacts on the OEE (Y) were variables $\mathrm{X} 1, \mathrm{X} 2, \mathrm{X} 3$, and $\mathrm{X} 4$, while the variables X5 (Yield/Scrap Losses) and X6 (Rework Losses) could not be calculated because each had a 0 (zero) value.

\section{Discussion}

\subsection{Main finding}

The main finding of this research is that the OEE score of this company was below the World Class Company standard, $w$ hich will be described in the following paragraphs.

First, after the data calculation and analysis of the variables related to this research, it is indicated that the OEE score in this company was $71.7 \%$, indicating that it was still below the World Class Company standard, with an availability rate of $86.3 \%$, performance efficiency rate of $83.6 \%$, and quality rate of $99.1 \%$.

Second, based on the calculation of the Six Big Losses, the most dominating factor affecting the low productivity of the weaving machine was first, the high reduced speed losses $(74.01 \%)$ and the second, the breakdowns losses (11.96\%)

\subsection{The result analysis of Overall Equipment Effectiveness}

The analysis of overall equipment effectiveness (OEE) was conducted to investigate the effectiveness of the weaving machine usage from January 2014 to June 2015. According to the results, the OEE score of the company had not yet fulfilled the standard of World Class Company of $71.7 \%$, where the three components to produce the OEE score were availability $(86.3 \%)$, performance efficiency $(83.6 \%)$, and quality rate $(99.1 \%)$. Based on further study it was known that the OEE score was low due to a low performance value.

\subsection{The result analysis using the Six Big Losses method}

The analysis of the Six Big Losses was conducted so that the company would become aware of the contribution of each factor in the Six Big Losses that affected the effectiveness of the weaving machine usage. This analysis was conducted by looking at the accumulative time loss in the Pareto chart.

Based on the analysis, out of the 6 categories in the Six Big Losses, the most dominant factor from January 2014 to June 2015 was reduced speed losses $(74.01 \%)$, breakdowns losses $(11.96 \%)$, idling and minor stoppages $(7.50 \%)$, and set up and adjustment losses $(6.50 \%)$. The analysis of the factors providing the greatest contribution toward the low effectiveness of the weaving machine was completed using the Fishbone diagram (Cause and Effect diagram). By using such a diagram, the causes of the high cumulative time loss can be observed in more detail.

\subsection{Analysis of Product Moment Pearson Correlation between OEE score and the Six Big Losses}

In addition to measuring the value of the Six Big Losses in this research, the Product Moment Pearson method was also used. Through this process, based on the analysis results of the Six Big Losses factors (reduced speed losses, breakdowns losses, idling and minor stoppages, set up and adjustment losses, yield/scrap losses dan rework losses) toward OEE variables, which are availability, performance efficiency, and quality rate, results demonstrate that the factors having impact on the correlations were reduced speed losses, breakdowns losses, idling and minor stoppages, set up and adjustment losses, while yield/scrap losses and rework losses could not be calculated as each had a 0 (zero) value.

The Product Moment Pearson correlation analysis was used to discover the relationship between the independent variable $(\mathrm{X})$ and the dependent variable $(\mathrm{Y})$, to investigate whether they were correlated or not. The result of the correlation between the Six Big Losses variables X1, X2, X3, X4, X5, and $\mathrm{X} 6$ toward OEE $\mathrm{Y}$ is explained in the following paragraph.

Based on the calculation of the Product Moment Pearson correlation between the OEE and the Six Big Losses, there is a correlation coefficient from $83.6 \%(\mathrm{r})$ between 0.543 and 0.716 , which means that there is a correlation between reduced speed losses (x1), breakdowns losses $\mathrm{x} 2$ ), idling and minor stoppages (x3), and set up and adjustment losses (x4) and the OEE score (y).

\subsection{Assessment of OEE value after implementation of suggested solutions}

For several suggested solutions that are considered to help minimize reduced speed losses (improving operator skills, adjusting production schedule, and implementing autonomous maintenance on the machines), it was expected that if they were applied and executed with a strong commitment, the value of the performance efficiency would improve. The value of performance efficiency was expected to increase by $10 \%$ from its former level, while the values of the availability and quality rate were to be maintained at the same level as their former values. 


\section{International Journal of Science and Research (IJSR) \\ ISSN (Online): 2319-7064}

Index Copernicus Value (2013): 6.14 | Impact Factor (2015): 6.391

Table 3: Assessment of OEE value after implementing suggested solutions

\begin{tabular}{|c|c|c|c|}
\hline Parameter & Condition & Before & After \\
\hline Availability & Maintained & $86.3 \%$ & $86.3 \%$ \\
\hline Performance Efficiency & Increased by $10 \%$ & $83.6 \%$ & $92.0 \%$ \\
\hline Quality Rate & Maintained & $99.1 \%$ & $99.1 \%$ \\
\hline OEE & & $71.7 \%$ & $78.7 \%$ \\
\hline
\end{tabular}

\section{The implications for the industry}

\subsection{Suggestions on measures to reduce the Six Big Losses}

Based on the analysis results of the OEE and the Six Big Losses values assessment, it can be summarized that the main cause of the low weaving machine effectiveness was the high rate of reduced speed losses, therefore becoming the company's priority to take corrective actions as the first step in improving the productivity and efficiency of the weaving machine. To improve the productivity of the weaving machine, there were several steps required to eliminate the most dominant factor of the Six Big Losses, which in this case, was reduced speed loss.

\subsection{Suggestions on the implementation of Total Productive Maintenance (TPM)}

The implementation of Total Productive Maintenance (TPM) was strongly necessary in the tire cord division to avoid unexpected downtime; the main goal was to involve operators in daily inspection and routine maintenance. By applying TPM maintenance, personnels could start using operator skills to conduct daily maintenance, and therefore it was expected that the maintenance personnels could start focusing more on thinking and improving skills proactively, as well as starting on minimizing failures. TPM has a broad concept for companies; in its implementation there is also a need to integrate each production activity towards better service through productivity improvement and machine efficiency.

Based on the analysis of the dominant factors of the Six Big Losses, reduced speed loss was one of the reasons of a high rate of losses in the production process of the tire cord division; this was a result of the machine operators still holding an an old principle saying, "I fix the machine, and you run it", meaning that the machine maintenance and reparation were still handled by mechanics and staff of the Engineering division. This posed disadvantages as it would require more time. Looking at the mentioned concept, it was recommended that autonomous maintenance on the weaving machine be applied.

Autonomous maintenance is the most important element in Total Productive Maintenance (TPM), which explains that an operator does not only run the production process, but is also involved in the simple maintenance process, so that indications of error will be detected as early as possible, and therefore avoiding total damage.

In this autonomous maintenance activity, every operator would be involved in maintenance and problems occurring on their machines. However, time and effort were required to train the operators to enhance their skills in autonomous maintenance.

\section{Conclusions and Suggestions}

Based on the results of this research, several conclusions can be drawn, as follows:

1) The average calculation results of the overall equipment effectiveness (OEE) in the weaving machine of the tire cord division had not yet fulfilled the World Class Company standard of $71.7 \%$, where the three components to obtain the OEE score are availibility $(86.3 \%)$, performance efficiency $(83.6 \%)$, and quality rate $(99.1 \%)$. This occurred because based on the result of the Six Big Losses, out of the six categories, the most dominant ones according to the Pareto chart were reduced speed losses, breakdowns losses, idling and minor stoppages, set up and adjustment losses.

2) Based on the test result using Product Moment Pearson correlation analysis between the OEE score and the Six Big Losses, the results obtained are that the correlation coefficient ( $\mathrm{r}$ ) was between 0.543 to 0.716 , which means that the reduced speed losses (X1), breakdowns losses (X2), idling and minor stoppages (X3), and set up and adjustment losses (X4) variables were correlated with the OEE score (Y).

3) The proposal to present a maintenance system on the weaving machine was to implement one TPM (Total Produktive Maintenance) pillar, namely autonomous maintenance, which seeks to improve operators' understanding on the weaving machine. Furthermore, it was expected to prompt the performance efficiency to rise from $83.6 \%$ to $92.0 \%$, and this would increase the OEE score from $71.7 \%$ to $78.7 \%$.

Based on the results analysis, discussion, and conclusion, the suggestion proposed is to establish strong commitment coming from the top management to implement Total Productive Maintenance (TPM), to train, and to review consistently, so that the implementation can be improved continuously (continuous improvement).

\section{References}

[1] Ahmed, T., Ali, S.M., Allama, M.M., \& Parvez, M.S. (2010). A Total Productive Maintenance (TPM) Approach to Improve Production Efficiency and Development of Loss Structure in a Pharmaceutical Industry. Global Journal of Management and Business Research, 10(2), 186-190.

[2] Higgins \& Mobley (2002). Maintenance Engineering Handbook, six edition. The McGraw-Hill Companies, Inc

[3] Assauri, Sofyan (2004) Manajemen Produksi dan Operasi, Lembaga Penerbit Fakultas Ekonomi Universitas Indonesia. Jakarta.

[4] Kedaria, Prof. Vivek A.Deshpande (2014). Implementation of Total Productive Maintenance Methodology : A Review, International Journal of Emerging Technology and Advanced Engineering

\section{Volume 5 Issue 7, July 2016


[5] Nakajima, S. (1988). Introductio to Total Productive Maintenance. Cambridge: Productivity Press inc

[6] Borris Steven. (2006). Total Productive Maintenance. New York: McGraw-Hill Companies, Inc

[7] Wireman Terry. (2005). Developing Performance Indicators for Managing Maintenance. New York: Industrial Press, Inc.

[8] Wakjira \& Singh (2012). Total Productive Maintenance: A Case Study in Manufacturing Industry. Global Journal of researches in engineering Industrial engineering 12

[9] Ahuja, I.P.S., \& Kahamba, J.S. (2008).Total Productive Maintenance, Literatur review and direction.

[10]Kumar, R.S. (2010). Application of Total Productive Maintenance (TPM) in the spinning mill. Practical Hints, 40-41.

[11] Sivakumar, D., Sapuan, S.M., Ismail, N., \& Ismail, M.Y. (2012). Application of Total Productive Maintenance to Reduce Non-Stick on Pad Problemin IC Packaging, International Journal of Engineering and Science, 1, 119

\section{Author Profile}

Akhmad Fauzi continued to a Diploma Program (D-3) in Chemical Engineering at Politeknik Gajah Tunggal Tangerang, graduating in 1990. In 2011, he continued his Bachelor's degree (S-1) in Industrial Engineering at Sekolah Tinggi Teknologi (STT) YUPPENTEK Tangerang, qualifying in 2013. He has work experience as a Process Control Engineer at PT. Gajah Tunggal Tbk in the tire cord Divison, Tangerang.

Gimbal Doloksaribu pursued an undergraduate program at Krisnadwipayana University, masters program at STIE IGI, and doctoral program at Universitas Negeri Jakarta. At present, he is a Professor at Mercu Buana University. 